\title{
Evaluasi Rumah Susun Pekunden Berdasarkan Kaidah Layak Huni dan Berkelanjutan
}

\author{
The Evaluation of Pekunden Flat Housing Coresponded to Adequate and \\ Sustainable Housing Principle
}

\author{
Kariza Dewi Wiryanti1 \\ Universitas Diponegoro, Semarang, Indonesia \\ Iwan Rudiarto2 \\ Universitas Diponegoro, Semarang, Indonesia
}

\begin{abstract}
Abstrak: Pertumbuhan penduduk di perkotaan yang semakin meningkat serta lahan yang terbatas membuat pembangunan Rumah Susun (Rusun) menjadi program andalan dalam pengentasan permukiman kumuh di kota. Hal ini lah yang juga dilakukan Pemerintah Kota Semarang dalam mengentaskan permukiman kumuh di Kelurahan Pekunden Kecamatan Semarang Tengah. Rusun Pekunden merupakan salah satu rusun yang dimiliki pemkot dan sudah berdiri 23 tahun silam dengan sistem kompensasi milik bagi penghuni asli permukiman dan selebihnya adalah sewa. Namun, sistem kepemilikan hunian yang tidak jelas dan kondisi fisik rusun yang menghawatirkan, mengindikasikan bahwa rusun tersebut tidak sesuai dengan kaidah hunian layak huni dan berkelanjutan. Tujuan dari penelitian ini adalah mengevaluasi Rusun Pekunden berdasarkan kaidah layak huni dan berkelanjutan. Metode yang dilakukan adalah metode kuantitatif dengan teknik analisis deskriptif. Beberapa aspek yang menjadi fokus dalam evaluasi ini adalah aspek fisik dan lingkungan, sosial dan ekonomi serta tenure security. Hasil dari penelitian ini menunjukkan bahwa Rumah Susun Pekunden saat ini tidak layak huni dan tidak berkelanjutan. Hal ini dilihat dari aspek fisik lingkungan yang masih berada di bawah garis ideal begitu juga dengan aspek sosial ekonomi dan tenure security. Aspek dengan nilai terendah pada evaluasi ini adalah aspek tenure security. Aspek ini lah yang kemudian perlu perhatian lebih dalam permasalahan di rusun ini.
\end{abstract}

Kata kunci: rumah susun; layak huni; berkelanjutan; evaluasi

\begin{abstract}
The increasing number of population and the limited amount of land in the urban area make vertical housing programme become a leading programme in reducing slum area. This programme was also implemented by Semarang City Government in order to reduce slum area in Pekunden Village of Central Semarang Subdistrict. The Pekunden Flat is one of the municipal government's flat housings that was built 23 years ago with ownership compensation system for the former tenants and rent system for the rest. However, the unsecure tenure and the improper physical condition of the vertical housing indicate that this housing does not notice the adequate and sustainable housing principle. The purpose of this research is to evaluate Pekunden Flat based on the adequate and sustainable housing principles. The research used quantitative method with descriptive analysis technique. The aspects used in this evaluation were physical and environmental aspects, economics and social aspects and also tenure security aspect. The result of this research shows that this Pekunden Flat is categorized as an inadequate and unsustainable housing. It can be seen from either physical and environmental aspect's result which stands below the ideal line or the social economics and tenure security aspects. Out of the aspects that has the lowest result in this evaluation is tenure security aspect. Therefore, this aspect needs more attention in Pekunden Flat case.
\end{abstract}

Keywords: flat housing; adequate; sustainable; evaluation

\footnotetext{
${ }^{1}$ Korespondensi Penulis: Universitas Diponegoro, Semarang, Indonesia Email: kariza.wiryanti@gmail.com

2 Korespondensi Penulis: Universitas Diponegoro, Semarang, Indonesia Email: iwan.rudiarto@undip.ac.id
} 


\section{Pendahuluan}

\section{Konsep Evaluasi}

\section{Pengertian Hunian Layak Huni dan Berkelanjutan}

Kondisi lahan perkotaan Indonesia yang mengacu pada mekanisme pasar, jumlah penduduk yang kian banyak dan sumber daya lahan yang cenderung tetap membuat harga rumah yang ada terutama di pusat kota tidak dapat dijangkau oleh MBR (Maysarakat Berpenghasilan Rendah). Akibatnya, hunian yang dihuni MBR cenderung padat dan tidak memperhatikan standar yang ada. Kondisi kumuh yang ditimbulkan tentu memiliki dampak besar. Beberapa permasalahan yang sering terjadi akibat permukiman kumuh diantaranya adalah bencana banjir dan kebakaran, angka kesehatan rendah serta angka kriminalitas yang tinggi (Prayitno, 2014:17).

Penentuan program pengentasan yang akan dilaksanakan bergantung pada kasus kekumuhan dan tujuan dari stakeholder pada kasus tersebut termasuk pemerintah kota dan masyarakat yang terlibat. Rumah Susun Pekunden merupakan salah satu program penanganan kumuh di pusat Kota Semarang yang dilakukan pemerintah kota pada tahun 1992. Rusun yang dibangun pada lahan permukiman padat ini awalnya merupakan permukiman yang didominasi oleh penduduk MBR dengan sarana dan prasarana dibawah standar. Permukiman tersebut terbentuk secara organik sehingga memiliki jalan atau akses terbatas yang mana tidak dapat diakses untuk persyaratan keselamatan seperti kebakaran, gempa bumi dan lainnya. Permukiman ini juga dilalui drainase atau aliran air yang seharusnya dapat memenuhi kebutuhan akan air, sebaliknya yang terjadi adalah permukiman ini mencemari aliran tersebut akibat limbah rumah tangga. Tingginya kebutuhan akan hunian di pusat kota membuat kawasan ini semakin padat dan semakin berbahaya karena terbatasnya sarana prasarana tersebut. Hal ini tidak hanya menjadi ancaman untuk masyarakat penghuni permukiman tersebut juga untuk perencanaan kota yang semakin tidak beraturan.

Tahun 2015 ini merupakan tahun ke 23 setelah rusun tersebut berdiri dan dihuni. Program penanganan permukiman kumuh berupa pembangunan rusun ini tentu ditujukan agar kawasan tersebut sudah terbebas dari masalah kekumuhan dan dapat menekan dampak yang ditimbulkan. Lebih jauh lagi bahkan harapannya masyarakat yang tinggal mendapatkan kehidupan yang lebih layak baik secara fisik, sosial dan ekonomi. Akan tetapi indikasi kondisi eksisting fisik bangunan yang tidak terawat bahkan cenderung rusak dan adanya isu kepemilikan hak yang masih belum jelas membuat rusun ini belum menjawab akan permukiman yang layak huni dan berkelanjutan.

Perencanaan yang baik haruslah melalui 10 tahapan perencanaan diantaranya: kepastian untuk adopsi perencanaan, membuat kerangka kerja organisasi untuk perencanaan, menentukan tujuan perencanaan, merumuskan sasaran, mengumpulkan dan menganalisis data, mengidentifikasi alternatif tindakan, menilai alternatif tindakan, memilih alternatif yang tepat, melakukan implementasi, melakukan monitor dan evaluasi (Conyers dan Hilss, 1984). Sepuluh tahapan diatas merupakan siklus yang mana dapat dilakukan berulang kali hingga tujuan dalam perencanaan tersebut dikatakan tercapai. Harus ditekankan bahwa banyaknya tahapan tersebut adalah saling berhubungan dan tidak ada tahapan yang dapat betul-betul terisolasi dari yang lainnya (Conyers dan Hilss, 1984). Evaluasi merupakan salah satu tahapan dalam siklus perencanaan yang mana cukup esensial dalam menentukan keberhasilan suatu perencanaan. Evaluasi bersifat menilai dan bertujuan agar perencanaan kedepan akan lebih baik dari sebelumnya.

"Evaluasi merupakan penilaian sistematik dan objektif atas proyek yang sedang berjalan ataupun proyek yang sudah terlaksana, program, atau kebijakan termasuk desain, implementasi dan hasil. Tujuannya adalah untuk memastikan hubungan dan pemenuhan atas objektifitas, efisiensi pengembangan, efektivitas, dampak, dan keberlanjutan. Evaluasi harus menyediakan informasi yang dapat dipercaya dan berguna, memungkinkan penggabungan pembelajaran menjadi proses membuat kebijakan baik untuk penerima ataupun pemberi evaluasi" (The OECD, 2002a dalam Kusek dan Rist 2004).

Tempat tinggal yang dikatakan sebagai hunian layak haruslah dapat dihuni, terjangkau, dan menunjukkan 4 penutup pertemuan kebutuhan penghuni secara fisik dan psiokologi sebaik melindungi mereka dari pengaruh buruk dan kecelakaan 


\section{Komponen dan Aspek Pendukung Rumah Susun}

(The American Public Housing Association (1964) dalam Amole dan lbem (2011)). Hunian layak huni meliputi struktur dan kecukupan internal dari unit tempat tinggal, ketersediaan fasilitas, harga pemilikan, kondisi lingkungan, dan kelayakan hunian rumah (Onibokum (1985) dalam Amole dan lbem (2011). Rumah Berkelanjutan dapat menghasilkan manfaat sosial seperti kepercayaan diri penghuni yang membaik, meningkatkan fungsi dan daya tahan, mengurangi pemeliharaan, reputasi yang lebih baik, dan yang lebih penting adalah meningkatkan kesehatan publik (Pilkington et al dalam Yang dan Yang (2015)). Hunian berkelanjutan tidak boleh, bagaimanapun, mencakup hanya aspek "hijau" efisiensi energy, akan tetapi juga penggunaan sumber daya, alam, sistem sosial budaya, pertumbuhan dan permintaan ekonomi dan gaya hidup generasi saat ini (Cole, Chiu dalam Yang dan Yang (2015). Berdasarkan beberapa pengertian diatas jelas disebutkan bahwa unsur dari penilaian layak huni dan berkelanjutan diantaranya adalah fisik lingkungan, sosial ekonomi dan tenure security. Unsut-unsur tersebut yang kemudian menjadi variabel-variabel dalam penelitian ini.

Rusun tentu memiliki komponen utama dan aspek pendukung di dalamnya. Peneliti mengkatagorikannya menjadi tiga aspek yaitu fisik dan lingkungan, sosial dan ekonomi, dan tenure security. Adapun penjelasan tiga aspek tersebut menutut beberapa literatur adalah sebagai berikut:

a. Fisik dan Lingkungan Rusun

a. Tata bangunan yang meliputi persyaratan peruntukan lokasi serta intensitas dan arsitektur bangunan; dan

b. Keandalan bangunan yang meliputi persyaratan keselamatan, kesehatan, kenyamanan dan kemudahan tertulis dalam UU No. 20 Tahun 2011. Persyaratan-persyaratan tersebut dijelaskan sebagai berikut:

- Persyaratan keselamatan yaitu kemampuan bangunan rumah susun mendukung beban muatan serta untuk mencegah dan menanggulangi bahaya kebakaran, dan bahaya petir;

- Persyaratan kesehatan meliputi sistem penghawaan, pencahayaan, sanitasi, dan penggunaan bahan bangunan;

- Persyaratan kenyamanan meliputi kenyamanan ruang gerak dan hubungan antar ruang, kondisi udara dalam ruang, pandangan, serta terhadap pengaruh tingkat getaran dan tingkat kebisingan;

- Persyaratan kemudahan meliputi kemudahan hubungan ke, dari, dan di dalam bangunan rumah susun serta sarana dan prasarana dalam pemanfaatan bangunan rumah susun. Pada persyaratan kemudahan ini bila ditinjau dari asas kemudahan terdapat juga unsur kemudahan fasilitas dan aksesibilitas bagi penyandang cacat dan lanjut usia (UU No. 20 Tahun 2011).

Pada penjelasan Undang Undang Rumah Susun disebutkan tetang lingkungan rumah susun yaitu sebidang tanah yang jelas yang diatasnya dibangun rumah susun, termasuk prasarana, sarana dan utilitas umum yang secara keseluruhan merupakan kesatuan tempat permukiman. Prasarana adalah kelengkapan dasar fisik lingkungan yang meliputi jaringan jalan, drainase, sanitasi, air bersih, dan tempat sampah. Sarana adalah fasilitas dalam lingkungan hunian rusun yang meliputi sarana sosial ekonomi (pendidikan, kesehatan, peribadatam dan perniagaan) dan sarana umum (ruang terbuka hijau, tempat rekreasi sarana olahraga, tempat pemakaman umum, sarana pemerintahan dan lain-lain). Sedangkan utilitas umum adalah penunjang pelayanan yang mencakup jaringan listrik, jaringan telepon dan jaringan gas. Terdapat poin tambahan yang disebutkan dalam Permen No. 14/PERMEN/M/2007 pada prasarana rusun yaitu adanya tangga dan selasar. Sedangkan pada utilitas harus dilengkapi dengan perlengkapan pemadam kebakaran (Permen No. 14/PERMEN/M/2007).

b. Sosial dan Ekonomi Rusun

Sosial ekonomi merupakan aspek yang bisa dijelaskan berdasar pada hubungan sosial yang ada dan faktor ekonomi pendukung didalamnya. Pada UU No. 20 Tahun 2011 dijlaskan Masyarakat rumah susun dapat membentuk forum pengembangan rumah susun. Forum pengembangan rumah susun ini difungsikan sebagai penampung aspirasi, membahas arah pengembangan rusun, 
meningkatkan peran dan pengawasan masyarakat, memberikan masukan kepada pemerintah dan/atau melakukan peran arbitrase dan mediasi di bidang penyelenggaraan rumah susun. Selain itu, terdapat sistem pembiayaan yang diatur yang meliputi lembaga pembiayaan, pengerahan dan pemupukan dana, pemanfaatan sumber biaya dan kemudahan atau bantuan pembiayaan (UU No. 20 Tahun 2011). Dengan kata lain, setiap rumah susun yang dibangun memiliki skema pembiayaan untuk kemudahan atau bantuan dalam perolehan unit rumah susun tersebut.

c. Kepemilikan Rusun

Sebagai jaminan akan hak kepemilikan, rusun juga memiliki setifikat hak yang sudah diatur. Kepemilikan rusun terbagi menjadi 2 yaitu SHM dan SKBG. Sertifikat hak milik sarusun yang selanjutnya disebut SHM sarusun adalah tanda bukti kepemilikan atas sarusun di atas tanah hak milik, hak guna bangunan atau hak pakai di atas tanah negara, serta hak guna bangunan atau hak pakai di atas tanah hak pengelolaan. Sertfikat selanjutnya adalah sertifikat kepemilikan bangunan gedung sarusun yang selanjutnya disebut SKBG sarusun merupakan tanda bukti kepemilikan atas sarusun di atas barang milik negara/daerah berupa tanah atau tanah wakaf dengan cara sewa (UU No. 20 Tahun 2011).

Kepemilikan rusun peruntukkan MBR memiliki skema bantuan didalamnya. Pada Undang-Undang tertulis bahwa bantuan kemudahan diberikan kepada MBR berupa kredit kepemilikan sarusun dengan suku bunga rendah, keringanan biaya sewa sarusun, asuransi dan penjaminan kredit pemilikan rumah susun, insentif perpajakan sesuai dengan ketentuan peraturan perundang-undangan, dan sertifikasi rusun (UU No. 20 Tahun 2011).

\section{Metode Penelitian}

Adapun teknik analisis yang digunakan oleh peneliti dalam evaluasi Rusun Pekunden adalah analisis deskriptif kuantitatif. Analisis deskriptif kuantitatif ini dilakukan untuk memberikan gambaran mengenai objek penelitian yang diolah menggunakan statistik deskriptif. Analisis deskriptif kuantitatif akan dilakukan pada keseluruhan aspek dengan pemberian skor pada masing-masing poin dalam aspek.

a. Fisik dan lingkungan

Evaluasi pada fisik lingkungan dilakukan pada 4 poin evaluasi yaitu kecukupan ruang, kondisi unit hunian, pengelolaan sarana, prasarana dan utilitas, serta kemudahan akses pencapaian prasarana dan utilitas. Kecukupan ruang dimaksudkan untuk mengetahui luasan lantai per orang. Pada SNI 03-1733-2004 Tentang Tata Cara Perencanaan lingkungan Perumahan di Perkotaan tercantum bahwa kebutuhan luas lantai minimum hunian per orang adalah 9,6 $\mathrm{m}^{2}$. Aturan tersebut berlaku untuk hunian tidak bertingkat. Aturan lainnya yaitu Keputusan Menteri Permukiman dan Sarana Pada Wilayah Nomor. 403/KPTS/M/2002 Tentang Pedoman Teknis Pembangunan Rumah Sederhana Sehat (Rs SEHAT) menyebutkan bahwa standar luasan lantai per jiwa di Indonesia adalah $9,0 \mathrm{~m}^{2}$. Sedangkan luas lantai perjiwa ambang batas dan skala internasional yaitu 7,2 $\mathrm{m}^{2}$ dan $12,0 \mathrm{~m}^{2}$. Berdasarkan aturan tersebut maka penyusun akan membagi kecukupan ruang berdasarkan 3 klasifikasi yaitu $<9 \mathrm{~m}^{2}, 9 \mathrm{~m}^{2}-11 \mathrm{~m}^{2}$, dan $>11 \mathrm{~m}^{2}$ Evaluasi pada poin lain yaitu kondisi unit hunian dan pengelolaan dan pencapaian sarana prasarana dan utilitas menggunakan skala likert dengan hasil sesuai degan pendapat masyarakat yang menghuni di rusun tersebut. skor 5 menjadi skor tertinggi dengan katagori "sangat baik", dan skor 1 menjadi skor terendah dengan katagori "sangat buruk". Berikut merupakan rincian skor pada evaluasi.

Tabel 1. Skor Aspek Fisik dan Lingkungan

\begin{tabular}{lllll}
\hline \multicolumn{1}{c}{$\begin{array}{c}\text { Kecukupan } \\
\text { Ruang }\end{array}$} & \multicolumn{1}{c}{$\begin{array}{c}\text { Kondisi Unit } \\
\text { Hunian }\end{array}$} & Pengelolaan & \multicolumn{1}{c}{$\begin{array}{c}\text { Kemudahan Akses } \\
\text { Pencapaian }\end{array}$} & Skor \\
\hline$>11 \mathrm{~m}^{2}$ & Sangat Baik & Sangat Baik & Sangat Baik & 5 \\
\hline- & Baik & Baik & Baik & 4 \\
\hline $9 \mathrm{~m} 2-11 \mathrm{~m}^{2}$ & Cukup & Cukup & Cukup & 3 \\
\hline- & Buruk & Buruk & Buruk & 2 \\
\hline$<9 \mathrm{~m}^{2}$ & Sangat Buruk & Sangat Buruk & Sangat Buruk & 1 \\
\hline Sumber : Analisis Penyusun, 2015 & & &
\end{tabular}


b. Tenure Security

Evaluasi pada aspek tenure security dilakukan pada 3 poin yaitu status kepemilikan, bantuan perolehan status dan skema pembiayaan, dan pergantian kepemilikan. Dasar dari penilaian status kepemilikan adalah karena aspek legalitas adalah penting untuk sebuah hunian. Aspek legalitas dapat dibuktikan dengan kepemilikan sertifikat. Hal inilah yang menjadi tolak ukur pada poin status kepemilikan.

Pada poin bantuan perolehan status dan skema pembiayaan didasarkan pada MBR selayaknya mendapatkan bantuan untuk memperoleh hunian. Pada UndangUndang tertulis bahwa bantuan kemudahan diberikan kepada MBR berupa kredit kepemilikan sarusun dengan suku bunga rendah, keringanan biaya sewa sarusun, asuransi dan penjaminan kredit pemilikan rumah susun, insentif perpajakan sesuai dengan ketentuan peraturan perundang-undangan, dan sertifikasi rusun (UU No. 20 Tahun 2011). Pergantian kepemilikan juga menjadi poin yang harus diperhitungkan dalam evaluasi. Hal ini terkait dengan sasaran penggunaan rusun agar tidak terjadi penyimpangan. Berikut merupakan skor yang diberikan pada evaluasi aspek tenure security:

Tabel 2. Skor Aspek Tenure Security

\begin{tabular}{|c|c|c|c|c|c|}
\hline \multirow{3}{*}{$\begin{array}{c}\text { Status } \\
\text { Kepemilikan }\end{array}$} & \multicolumn{3}{|c|}{ Bantuan Perolehan Status dan Skema } & \multirow{3}{*}{$\begin{array}{l}\text { Pergantian } \\
\text { Kepemilikan }\end{array}$} & \multirow{3}{*}{ Skor } \\
\hline & & Pembiaya & & & \\
\hline & \multicolumn{2}{|c|}{$\begin{array}{c}\text { Keberadaan Bantuan } \\
\text { Status }\end{array}$} & \multirow{2}{*}{\begin{tabular}{l}
\multicolumn{1}{c}{$\begin{array}{c}\text { Skema } \\
\text { Pembiayaan }\end{array}$} \\
Terdapat \\
bantuan \\
skema \\
pembiayaan
\end{tabular}} & & \\
\hline $\begin{array}{l}\text { Memiliki } \\
\text { sertifikat } \\
\text { kepemilikan }\end{array}$ & $\begin{array}{l}\text { Terdapat } \\
\text { perolehan } \\
\text { kepemilikan }\end{array}$ & $\begin{array}{r}\text { bantuan } \\
\text { status }\end{array}$ & & $\begin{array}{l}\text { Kepemilikan } \\
\text { tidak } \\
\text { berganti }\end{array}$ & 5 \\
\hline- & - & & - & - & - \\
\hline- & - & & - & - & - \\
\hline- & - & & - & - & - \\
\hline $\begin{array}{l}\text { Tidak } \\
\text { memiliki } \\
\text { sertifikat } \\
\text { kepemilikan }\end{array}$ & $\begin{array}{l}\text { Tidak } \\
\text { bantuan } \\
\text { kepemilikan }\end{array}$ & $\begin{array}{r}\text { terdapat } \\
\text { status }\end{array}$ & $\begin{array}{l}\text { Tidak terdapat } \\
\text { bantuan } \\
\text { skema } \\
\text { pembiayaan }\end{array}$ & $\begin{array}{l}\text { Kepemilikan } \\
\text { berganti }\end{array}$ & 1 \\
\hline
\end{tabular}

c. Sosial dan Ekonomi

Evaluasi pada aspek sosial dan ekonomi dilakukan pada 5 poin. Pada poin pendapatan skor tertinggi akan diberikan pada hunian dengan penghasilan sesuai dengan MBR. Peraturan Menteri Negara Perumahan Rakyat Nomor: 06/PERMEN/M/2006 menyebutkan bahwa MBR adalah keluarga atau rumah tangga yang berpenghasailan sampai dengan dua juta rupiah per bulan (Permen No. 06/PERMEN/M/2006). Meski demikian, setiap kota atau daerah Indonesia juga memiliki UMK (Upah Minimum Kota) yang berbeda. UMK Kota Semarang pada tahun 2015 ini adalah Rp 1.685.000.

Pada poin ketentuan jarak, skor tertinggi akan diberikan kepada hunian yang ditempati oleh pekerja dengan jarak terdekat sampai dengan $400 \mathrm{~m}$. Peraturan Menteri Pekerjaan Umum Tentang Pedoman Perencanaan, Penyediaan, dan Pemanfaatan Prasarana dan Sarana Jaringan Pejalan Kaki di Kawasan Perkotaan menyatakan bahwa di Indonesia, dengan cuaca yang panas, orang hanya ingin menempuh $400 \mathrm{~m}$ untuk berjalan. Sedangkan untuk aktivitas berbelanja, keinginan berjalan tidak lebih dari 300m (Permen PU No. 3/PRT/M/2014).

Pada evaluasi transportasi, dilakukan dengan menggunakan pembobotan atas pemilihan moda. Bobot terbesar adalah berjalan kaki dan selanjutnya diikuti dengan poin yang lebih kecil oleh penggunaan kendaraan umum dan kendaraan pribadi. Sedangkan pada poin lainnya dilakukan menggunakan skala likert dengan hasil sesuai degan pendapat masyarakat yang menghuni di rusun tersebut. skor 5 menjadi skor tertinggi dengan katagori "sangat baik", dan skor 1 menjadi skor terendah dengan katagori "sangat buruk". Berikut merupakan rincian skor pada evaluasi. 
Tabel 3. Skor Aspek Sosial dan Ekonomi

\begin{tabular}{|c|c|c|c|c|c|c|c|}
\hline \multirow[b]{2}{*}{ Pendapatan } & \multicolumn{2}{|c|}{ Jarak dan Transportasi } & \multicolumn{2}{|c|}{ Sosial } & \multirow[b]{2}{*}{ Kesehatan } & \multirow[b]{2}{*}{ Kriminalitas } & \multirow[b]{2}{*}{ Skor } \\
\hline & Jarak & Transportasi & Interaksi & $\begin{array}{c}\text { Aktif } \\
\text { Kegiatan }\end{array}$ & & & \\
\hline $\begin{array}{c}\mathrm{Rp} 0-\mathrm{Rp} \\
2.000 .000\end{array}$ & $\begin{array}{c}1 \mathrm{~m}- \\
400 \mathrm{~m}\end{array}$ & Jalan kaki & $\begin{array}{l}\text { Sangat } \\
\text { Sering }\end{array}$ & $\begin{array}{l}\text { Sangat } \\
\text { Sering }\end{array}$ & $\begin{array}{l}\text { Sangat } \\
\text { Sering }\end{array}$ & Sangat Sering & 5 \\
\hline $\begin{array}{c}\text { Rp } 2.000 .001 \\
-R p \\
3.000 .000 \\
\end{array}$ & $\begin{array}{c}401 \mathrm{~m} \\
-800 \\
\mathrm{~m}\end{array}$ & - & Sering & Sering & Sering & Sering & 4 \\
\hline $\begin{array}{c}\text { Rp } 3.000 .001 \\
-R p \\
4.000 .000 \\
\end{array}$ & $\begin{array}{c}801 \mathrm{~m} \\
-1.200 \\
\mathrm{~m}\end{array}$ & $\begin{array}{l}\text { Kendaraan } \\
\text { Umum }\end{array}$ & Cukup & Cukup & Cukup & Cukup sering & 3 \\
\hline $\begin{array}{c}\mathrm{Rp} \\
4.000 .001- \\
\mathrm{Rp} \\
5.000 .000\end{array}$ & $\begin{array}{l}1.201 \mathrm{~m} \\
-1.600\end{array}$ & - & Jarang & Jarang & Jarang & Jarang & 2 \\
\hline $\begin{array}{c}>\mathrm{Rp} \\
5.000 .000\end{array}$ & $>1.600$ & $\begin{array}{l}\text { Kendaraan } \\
\text { Pribadi }\end{array}$ & $\begin{array}{l}\text { Tidak } \\
\text { Pernah }\end{array}$ & $\begin{array}{l}\text { Tidak } \\
\text { Pernah }\end{array}$ & $\begin{array}{l}\text { Tidak } \\
\text { Pernah }\end{array}$ & Tidak Pernah & 1 \\
\hline
\end{tabular}

Sumber : Analisis Penyusun, 2015

Hasil Pembahasan
Evaluasi yang dilakukan berdasarkan pada kaidah layak huni dan berkelanjutan mencakup ke dalam 3 aspek yaitu fisik dan lingkungan, tenure security dan sosial ekonomi. Bedasarkan evaluasi yang dilakukan, warga rusun tersebut merasa cukup akan fisik dan lingkungan serta sosial ekonomi meskipun dalam observasi yang dilakukan penyusun tidak demikian. Terdapat beberapa poin pada aspek tersebut yang dirasa kurang bahkan tidak sesuai dengan yang seharusnya. Akan tetapi permasalahan pokok pada aspek kelayakan dan keberlanjutan yang dialami oleh rusun ini adalah security of tenure. Permasalahan yang masih belum ada titik temu ini masih menjadi polemik antara pihak pemerintah kota sebagai penyelenggara rusun dan warga rusun sebagai penerima (penghuni) rusun.

Tabel 4. Skor Rata-Rata Aspek Fisik dan Lingkungan

\begin{tabular}{lrrrr}
\hline & $\begin{array}{c}\text { Kecukupan } \\
\text { Ruang }\end{array}$ & $\begin{array}{c}\text { Kondisi } \\
\text { Unit Hunian }\end{array}$ & Pengelolaan & \multicolumn{1}{c}{$\begin{array}{c}\text { Akses } \\
\text { Pencapaian }\end{array}$} \\
\hline Kondisi Aktual & 2.65 & 3.04 & 3.14 & 3.30 \\
\hline Kondisi Ideal & 5.00 & 5.00 & 5.00 & 5.00 \\
\hline
\end{tabular}

Sumber : Analisis Penyusun, 2015

Permasalahan yang terdapat pada fisik dan lingkungan berdasarkan hasil kuesioner adalah kecukupan ruang. Terlihat poin kecukupan ruang pada Tabel 4 memiliki titik paling rendah diantara lainnya yaitu 2.65. Angka dibawah tiga didefinisikan memiliki kecukupan ruang kurang dari $9 \mathrm{~m}^{2}$. Sedangkan angka ideal pada kondisi di Indonesia adalah $9.5 \mathrm{~m}^{2}$ dan skala internasional adalah $12 \mathrm{~m}^{2}$. Meski pada Gambar 1 poin lainnya berada pada titik 3 dengan definisi cukup, hasil yang berbeda didapat penyusun dengan observasi. Banyaknya kerusakan fisik yang ditemukan dan kekurangan sarana keselamatan membuat gambar dibawah belum dapat menggambarkan kondisi yang sebenarnya.

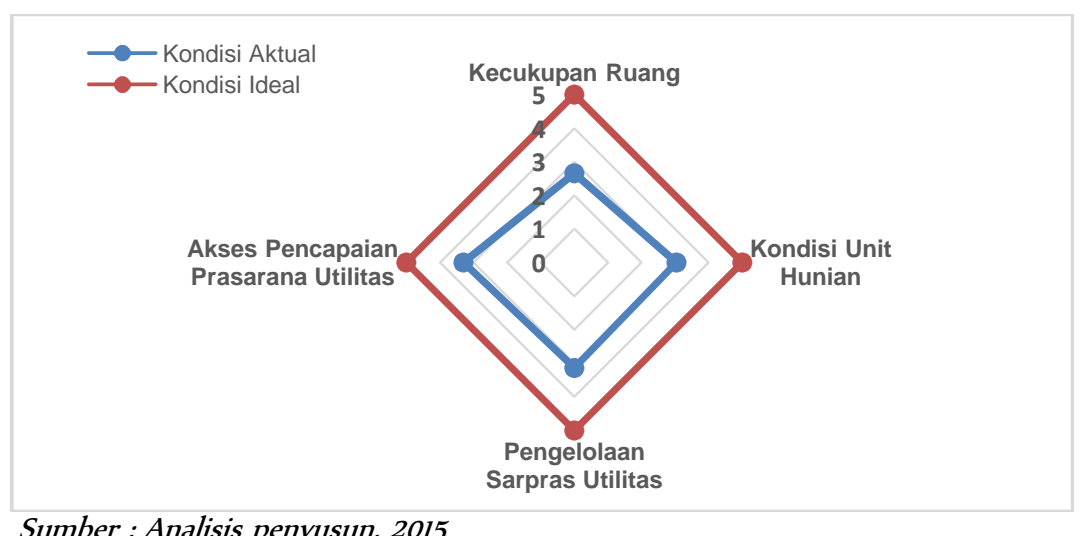

Sumber : Analisis penyusun, 2015

Gambar 1. Aspek Fisik dan Lingkungan 
Pada aspek tenure security, rusun ini memiliki nilai yang sebagian besar poin berada pada titik rendah. Titik terendah terjadi pada poin status kepemilikan karena tidak satu pun responden yang memiliki kejelasan akan kepemilikan yang dibuktikan dengan sertifikan hak atas rusun. Poin yang juga memiliki angka terendah yaitu 1 adalah keberadaan bantuan status. Hingga saat ini, bantuan akan perolehan status tidak diterima oleh warga yang pada kasus ini merupakan warga terdampak atas pembangunan rusun ini. Hal poin rendah berikutnya adalah skema pembiayaan. Pada dasarnya terdapat perjanjian skema pembiayaan yang disepakati antara pemerintah kota sebagai pembangun dan masyarakat sebagai pihak penerima. Akan tetapi skema pembiayaan tersebut tidak berjalan dengan semestinya. Bahkan sebagian besar warga tidak melakukan skema pembiayaan apapun. Penyusun menggabungkan poin ini karena adanya keterkaitan antara keduanya.

Tabel 5. Skor Rata-Rata Aspek Tenure Security

\begin{tabular}{lccc}
\hline & Status Kepemilikan & $\begin{array}{c}\text { Keberadaan Bantuan } \\
\text { Status dan skema } \\
\text { pembiayaan }\end{array}$ & $\begin{array}{c}\text { Pergantian } \\
\text { Kepemilikan }\end{array}$ \\
\hline $\begin{array}{l}\text { Kondisi } \\
\text { Aktual }\end{array}$ & 1.00 & 1.00 & 3.61 \\
\hline Kondisi ldeal & 5.00 & 5.00 & 5.00 \\
\hline Sumber : Analisis Penyusun, 2015 & &
\end{tabular}

Meskipun pergantian kepemilikan merupakan poin yang memiliki angka tertinggi dalam kasus ini yaitu 3.61, namun rusun yang dibangun sebagai kompensasi tidak selayaknya berpindah tangan. Pada evaluasi ini yang dikatagorikan berpindah tangan adalah penghuni yang bukan hak waris ataupun yang dihuni oleh penghuni asli melainkan di jual kepada pihak lain. Ketiga poin tersebut dapat dilihat pada Gambar 2 berikut.

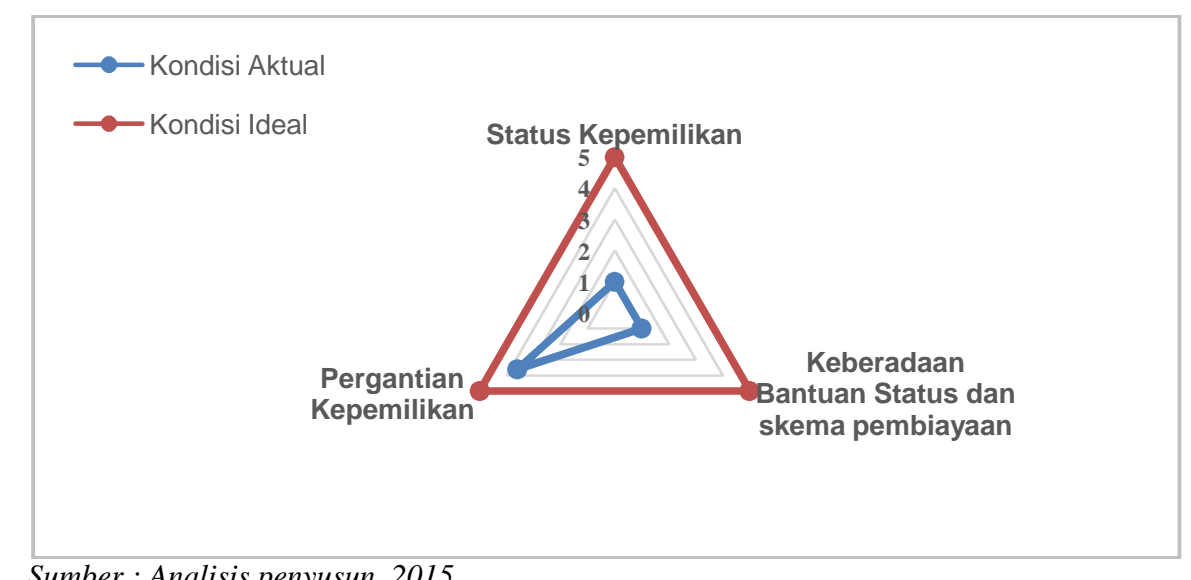

Gambar 2. Aspek Tenure Security

Pada aspek sosial dan ekonomi, evaluasi dilakukan pada 5 poin yaitu pendapatan, jarak dan transport, sosial yang menggambarkan interaksi warga, kesehatan dan kriminalitas. Titik yang berada di titik terendah berdasarkan hasil kuesioner yang dilakukan adalah jarak dan transport yaitu pada rata-rata jawaban pada 2.10. Hal ini dikarenakan hampir sebagian besar warga menggunakan kendaraan pribadi dan memiliki jarak yang terlampau jauh dari rusun. Pada kondisi ideal hal ini tentu sangat tidak dianjurkan karena ketidakefisienan dan tidak berkelanjutan.

Poin yang juga terlihat rendah pada aspek ini adalah pendapatan dan sosial. Rusun Pekunden ini merupakan rusun yang dibangun peruntukan MBR yang seharusnya dihuni oleh MBR. Akan tetapi berdasarkan hasil kuesioner yang dilakukan, sebagian besar warga memiliki pendapatan yang tidak terkatagorikan 
sebagai MBR dengan jawaban rata-rata adalah 3.20 yaitu $R p$ 3.000.001 - Rp 4.000.000. Hal ini terjadi bukan hanya karena adanya dominasi pada level penghasilan tersebut tetapi banyaknya penghasilan yang juga diatas pada level ratarata. Hal ini tentu tidak seharusnya terjadi dan diperlukan suatu tindakan pengendalian agar pembangunan rusun ini tepat sasaran.

Tabel 4. Skor Rata-Rata Aspek Sosial dan Ekonomi

\begin{tabular}{lrrrrr}
\hline & Pendapatan & $\begin{array}{c}\text { Jarak dan } \\
\text { Transport }\end{array}$ & Sosial & Kesehatan & Kriminalitas \\
\hline $\begin{array}{l}\text { Kondisi } \\
\text { Aktual }\end{array}$ & 3.20 & 2.10 & 3.15 & 4.67 & 4.96 \\
\hline Kondisi ldeal & 5.00 & 5.00 & 5.00 & 5.00 & 5.00 \\
\hline
\end{tabular}

Sumber : Analisis Penyusun, 2015

Poin sosial memiliki titik rendah dikarenakan pendapat sosial yang mengatakan bahwa interaksi dan partisipasi warga yang cukup. Titik 3 pada aspek ini diartikan sebagai interaksi sosial yang cukup. Sehingga tidak terdapat permasalahan yang berarti pada poin sosial ini.

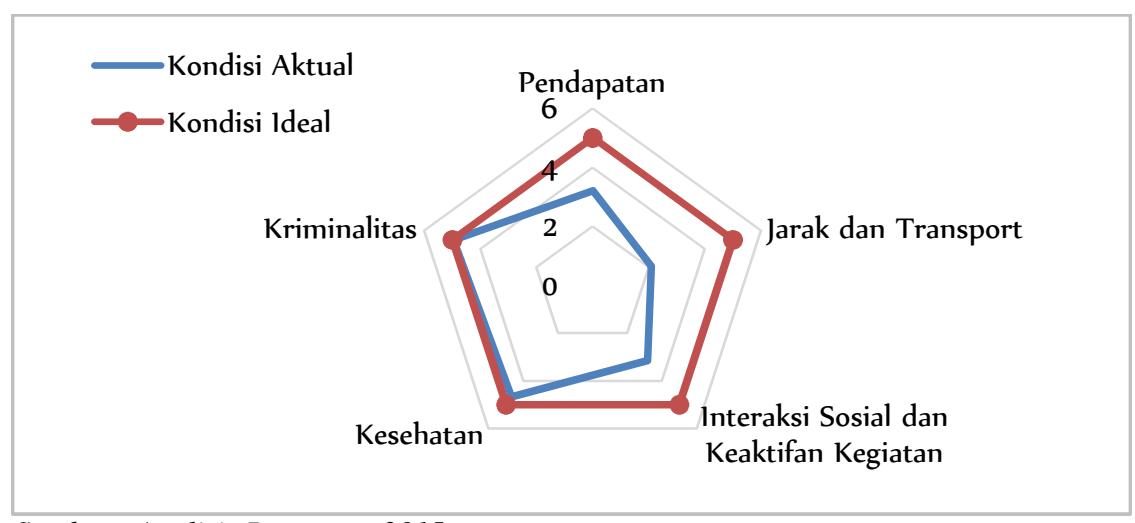

Sumber: Analisis Penyusun, 2015

\section{Gambar 3. Aspek Sosial dan Ekonomi}

Berdasarkan evaluasi yang dilakukan, dapat disebutkan bahwa Rumah Susun Pekunden saat ini tidak memenuhi kaidah layak huni dan berkelanjutan. Hal ini dapat dilihat pada Gambar 4 bahwa secara keseluruhan aspek rusun ini berada di bawah garis ideal. Aspek paling jauh dari garis ideal adalah Tenure Security yang berada pada wilayah titik 1 .

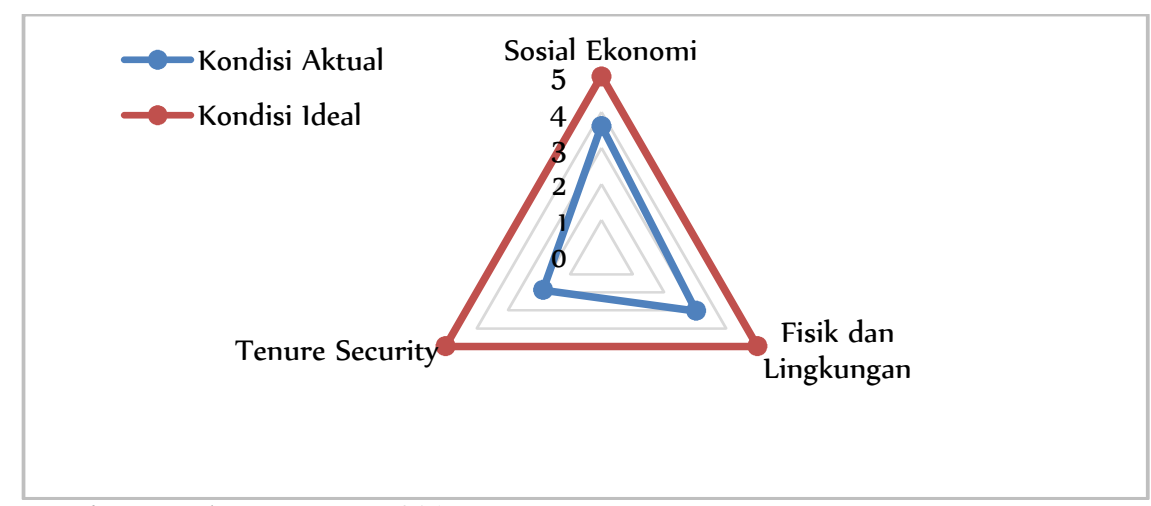

Sumber : Analisis penyusun, 2015

Gambar 4. Layak Huni dan Berkelanjutan 
Grafik ini pada dasarnya tidak menggambarkan kondisi Rusun Pekunden yang sesungguhnya pada aspek fisik dan lingkungan. Aspek fisik dan lingkungan seharusnya memiliki angka yang lebih rendah dibanding dengan yang tertera pada gambar. Hal ini dikarenakan kondisi fisik dan lingkungan rusun berdasarkan data observasi yang buruk. Akan tetapi data observasi tidak lah dapat diangkakan sehingga tidak dapat tergambar kondisi real lapangan.

Kesimpulan

\section{Daftar Pustaka}

Berdasarkan hasil evaluasi yang dilakukan, Rumah Susun Pekunden merupakan rusun yang tidak layak huni dan tidak berkelanjutan. Hal ini disimpulkan berdasarkan evaluasi melalui 3 aspek utama yaitu aspek fisik lingkungan, tenure security dan sosial ekonomi.

Hasil evaluasi menunjukkan bahwa rusun tersebut berada di bawah garis kondisi ideal pada ketiga aspek tersebut. Aspek tenure security memiliki nilai rendah pada keseluruhan poin yaitu status kepemilikan, keberadaan bantuan status dan skema pembiayaan, dan pergantian kepemilikan. Rendahnya aspek ini diakibatkan oleh tidak adanya kejelasan hak kepemilikan yang dibuktikan dengan tidak adanya sertifikat sebagai bukti sah kepemilikan pada seluruh pemilik unit rusun. Selain itu juga banyaknya warga bukan terdampak yang menempati unit rusun peruntukan warga terdampak membuat nilai yang ada pada poin di aspek ini rendah.

Aspek yang juga rendah adalah fisik dan lingkungan. Pada aspek ini, rendahnya titik belum dapat menggambarkan secara real kondisi hunian karena evaluasi dihitung berdasarkan persepsi warga tanpa memperhitungkan hasil observasi. Berdasarkan observasi yang dilakukan, tidak adanya alat pemadam kebakaran membuat aspek ini rendah pada poin keselamatan. Ditemukannya kerusakan di beberapa titik seperti jembatan dan atap rusun juga minimnya ruang jemur rusun yang ada mendukung rendahnya aspek fisik dan lingkungan. Keadaan sosial ekonomi rusun juga dapat dikatakan belum ideal. Jarak antara tempat kerja dan hunian yang terlampau jauh membuat penilaian akan keberlanjutan pada aspek ini rendah. Selain itu dominasi penghuni menggunakan kendaraan pribadi menuju tempat kerja juga membuat hunian ini termasuk ke dalam hunian yang tidak berkelanjutan.

Keadaan ini tentu bukanlah keadaan yang seharusnya terwujud akan suatu perencanaan. Rumah Susun Pekunden yang dibangun atas dasar program membangun tanpa menggusur tentu mengharapkan adanya kesejahteraan sosial masyarakat yang tinggal di dalamnya. Tidak semata-mata membuat penataan perkotaan lebih baik, namun lebih jauh lagi, masyarakat sebagai subjek haruslah memiliki hak untuk penghidupan yang baik, tidak terancam oleh suatu apapun baik kondisi fisik maupun kesejahteraan. Sehingga tujuan akan hunian sebagai sarana membinaan keluarga, cerminan harkat dan martabat penghuninya dapat terwujud dengan baik.

Amole, O.O dan Eziyi O. Ibem. 2011. “Assesment of The Qualitative Adequacy of Newly Constructed Public Housing in Ogun State, Nigeria." Property Management Vol. 29 No. 3. 2011 Emerald lnsigt.

Badan Standarisasi Nasional. Standar Nasional Indonesia. SNI 03-1733-2004 Tentang Tata Cara Perencanaan Lingkungan Perumahan di Perkotaan.

Conyers, Diana dan Peter Hills. 1984. An Introduction to Development Planning in The Third World Scotland : Pitman Press Ltd., Bath, Avon.

Kusek, Jody Zall dan Ray C. Rist. 2004. Ten Step to A Results-Based Monitoring an Evaluation System. Washington DC : The International Bank for Reconstruction and Development / The World Bank.

Menteri Negara Perumahan Rakyat Republik Indonesia. Peraturan Menteri Negara Perumahan Rakyat Nomor : 06/PERMEN/M/2006 Tentang Pembangunan/Perbaikan Perumahan Swadaya Melalui Kredit/Pembiayaan Mikro dengan Dukungan Fasilitas Subsidi Perumahan.

Menteri Negara Perumahan Rakyat. Peraturan Menteri Perumahan Rakyat Nomor: 14/PERMEN/M/2007 Tentang Pengelolaan Rumah Susun Sederhana Sewa.

Menteri Pekerjaan Umum Republik Indonesia. Peraturan Menteri Pekerjaan Umum Nomor : 03/PRT/M/2014 Tentang Pedoman Perencanaan, Penyediaan, dan Pemanfaatan Prasarana dan Sarana Jaringan Pejalan Kaki di Kawasan Perkotaan.

Menteri Perumahan dan Prasarana Wilayah Republik Indonesia. Keputusan Menteri Permukiman dan Prasarana Wilayah Nomor :403/KPTS/M/2002 Tentang Pedoman Teknis Pembangunan Rumah Sederhana Sehat (Rs SEHAT).

Prayitno, Budi. 2014. Skema Inovatif Penanganan Permukiman Kumuh. Yogyakarta: Gajah Mada University Press.

DOI: HTTP://DX.DOI.ORG/10.14710/RUANG.1.4.241-250 
Undang-Undang Republik Indonesia. UU No. 20 Tahun 2011 Tentang Rumah Susun.

Yang, Jay dan Zhengyu Yang. 2015. "Critical Factors Affecting The Implementation of Sustainable Housing in Australia." Journal of Housing and The Built Environment (2015) 30:275-292 Springe. 